\title{
Assay of Total Plasma Apolipoprotein B Concentration in Human Subjects
}

\author{
Gustav Schonfeld, Robert S. Lees, P. K. George, and \\ Barbara PFLeger \\ From the Arteriosclerosis and Clinical Research Centers, Massachusetts Institute \\ of Technology, Cambridge, Massachusetts 02142
}

A BStract We have developed a double antibody radioimmunoassay (RIA) for human apolipoprotein $B$ $(\mathrm{ApoB})$. The assay measures not only the ApoB content of $\beta$-lipoproteins (low density lipoproteins [LDL]) but also that contained in the other lipoproteins in plasma.

Purified lymph and plasma chylomicrons and plasma very low density lipoproteins (VLDL) produced displacement curves in the assay system which paralleled those produced by pure LDL. Thus, the ApoB found in chylomicrons, VLDL, and LDL were immunologically identical. ApoB accounted for about 25 and $35 \%$, respectively, of the total protein of chylomicrons and VLDL by RIA. VLDL and LDL preparations from normal and hyperlipoproteinemic subjects also produced parallel displacement curves, suggesting that the ApoB of normal and hyperlipoproteinemic subjects were immunologically identical. High density lipoproteins and abetalipoproteinemic plasma displaced no counts, nor did the sera of several animal species produce any useful displacement curves in this system.

The fasting total plasma ApoB concentration of normal subjects was $83 \pm 16 \mathrm{mg} / \mathrm{dl}$ (mean $\pm \mathrm{SD}$ ). ApoB levels were high in Type II $(162 \pm 16)$, and less so in

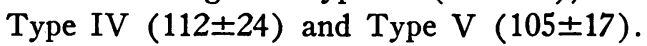

When plasma ApoB concentration in Type IV patients was graphed against plasma glycerides, two subpopulations, which may represent different genetic or biochemical subgroups, were apparent.

Dr. Schonfeld's and Ms. Pfleger's present address is: Lipid Research Center, Washington University School of Medicine, St. Louis, Mo. 63110.

Received for publication 2 March 1973 and in revised form 30 August 1973.
ApoB concentration in individuals on constant diet and drug regimen was stable over weeks to months. Greater than $90 \%$ of ApoB of normal and Type II subjects was in the $d>1.006$ plasma fraction. By contrast, only $50-80 \%$ of $\mathrm{ApoB}$ was in the $d>1.006$ fraction in Types IV and V. Thus, hypertriglyceridemia was associated primarily with a redistribution of $A p o B$ to the lighter density fractions; by contrast, in hypercholesterolemia absolute ApoB concentration was markedly increased.

\section{INTRODUCTION}

The lipoproteins of plasma are complex structures. Each lipoprotein class is comprised of several kinds of lipids and one or more polypeptides - the apolipoproteins (1-3). The various components of the lipoproteins have diverse metabolic fates (4) and different half-lives (5-9) in plasma.

The lipoproteins have been more intensively studied in terms of their. lipid than of their protein moieties, because, for most of the apolipoproteins, the available methodology is cumbersome, time-consuming, and applicable only to a relatively small number of samples at a time (10-15). Recently, simpler assays capable of measuring apolipoprotein B $\left(\mathrm{ApoB}^{\mathbf{1}}\right.$ in human low density lipoproteins (LDL) $(16,17)$ and in rat plasma have become available (18). However, the assay used for assessing human ApoB depends upon the diffusion

${ }^{1}$ Abbreviations used in this paper: ApoB, apolipoprotein B; BSA, bovine serum albumin; d-LDL, delipidated low density lipoprotein; LDL, low density lipoprotein; RIA, radioimmunoassay; SDS, sodium dodecyl sulfate; VLDL, very low density lipoprotein. 
of lipoproteins through agarose. It is therefore not applicable to $d<1.006$ fractions of plasma, since very low density lipoproteins (VLDL) and chylomicrons cannot penetrate the agarose used in this radial immunodiffusion assay. Other methods based on the assessment of the turbidity (19) or volume ("immunocrit") (20) of immunoprecipitates may be limited by the variation in size of the immunoprecipitates produced by lipoproteins of different sizes. The radioimmunoassay (RIA) technique does not suffer from the above limitations; it therefore promised to be a useful technique for the assessment of plasma ApoB levels.

We describe here a double antibody RIA for human ApoB-protein and report its application to the immunologic characterization of $\mathrm{ApoB}$ in isolated lipoproteins and plasma fractions. We include, as well, the concentrations of ApoB in whole plasma in normal subjects and in patients with various types of hyperlipoproteinemia. Part of this work has been reported in abstract form (21).

\section{METHODS}

Preparation of $L D L$. LDL was isolated from the plasmas of normal subjects as follows: blood was collected from subjects in the fasting state into tubes containing disodium EDTA $(1 \mathrm{mg} / \mathrm{ml})$. Plasma was separated by centrifugation for $20 \mathrm{~min}$ at $2,500 \mathrm{~g}$, and its solvent density adjusted to 1.050 with solid $\mathrm{NaCl}$. It was then centrifuged in a Beckman model L2-65B preparative ultracentrifuge in a 30 rotor (Beckman Instruments, Inc., Spinco Div., Palo Alto, Calif.). Two runs were performed at $d=1.050$; each was at $30,000 \mathrm{rpm}$ for $36 \mathrm{~h}$ at $15^{\circ} \mathrm{C}$. Tubes were sliced in the clear mid-zone, and infranates were discarded. The density of the "washed" $d=1.050$ supernates were brought to a calculated density of 1.025 by the addition of EDTAsaline ( $0.165 \mathrm{M} \mathrm{NaCl}, 1 \mathrm{mM}$ in $\left.\mathrm{Na}_{2}-\mathrm{EDTA}, \mathrm{pH} \mathrm{8}\right)$. Ultracentrifugation was then carried out as above, but for 20 instead of $36 \mathrm{~h}$. The supernates of these runs were discarded, and the infranates containing the LDL were dialyzed against EDTA-saline. The density range 1.0251.050 was chosen, because it was found empirically to contain the major LDL peak and to exclude VLDL, high density lipoproteins (H.DL), and LP-a.

These LDL preparations formed single Oil Red O-stainable immunoprecipitin arcs in the $\beta$-position on immunoelectrophoresis with antihuman sera (1). Albumin and other globulins were not detectable by double immunodiffusion and immunoelectrophoreses. LDL prepared in this way was used $(a)$ as the immunizing antigen for producing antihuman LDL, $(b)$ as the LDL-protein standard in the assay and $(c)$ as the source of ${ }^{120}$ I-labeled LDL. The protein contents of these and other lipoprotein fractions were determined by the method of Lowry, Rosebrough, Farr, and Randall (22), corrected as suggested by Margolis and Langdon (23).

Preparation of antisera. Whole LDL; and LDL which had been delipidated (d-LDL) with ethanol: ether $(3: 1)$ and resolubilized in $0.2 \mathrm{M}$ Tris buffer, $\mathrm{pH} 8,0.050-0.1 \mathrm{M}$ in sodium decyl sulfate (SDS), were used as immunizing antigens. d-LDL was dialyzed against $0.050 \mathrm{NH}_{4}$ $\mathrm{HCO}_{8},-0.002 \mathrm{M}$ SDS, $\mathrm{pH} 8$, before injection. $1 \mathrm{mg}$

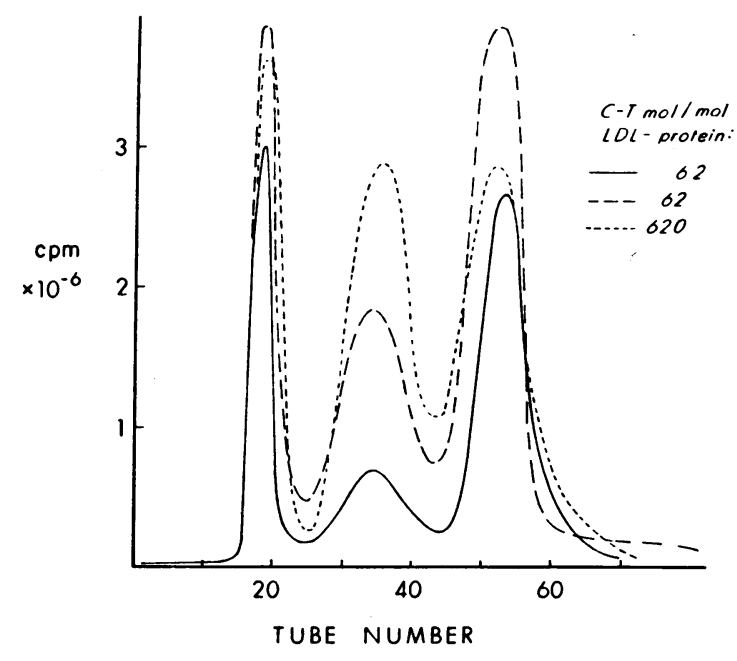

FIgure 1 The effect of Chloramine-T (C-T) on the iodination of human LDL. The first gel filtration peak (Sephadex G-200) contains most of the immunoprecipitable material. Peak 1 was used as [185I]LDL after a second filtration through Sephadex G-200.

LDL-protein, in $1 \mathrm{ml}$, was emulsified with an equal volume of Freund's complete adjuvant and injected subcutaneously into rabbits (1). Rabbits were bled 8-10 days after the last of three injections at 2-3 wk intervals. Antibody to rabbit $\gamma$-globulin isolated by DEAE cellulose chromatography was prepared in goats as recommended by Williams and Chase (24).

Iodination of $L D L . \quad\left[{ }^{120} \mathrm{I}\right] \mathrm{LDL}$ was prepared by the method of Greenwood, Hunter, and Glover, (25) as follows: $1 \mathrm{mCi}$ of sodium ${ }^{125} \mathrm{I}$ (about $4 \mu 1$ ) (New England Nuclear, Boston, Mass.) was dried under nitrogen, and $100 \mu 1$ of $0.5 \mathrm{M}$ phosphate buffer, $\mathrm{pH} 7.6$, was added to the test tube. 10-25 $\mu \mathrm{g}$ of LDL standard, which had been desalted on a $0.9 \times 15 \mathrm{~cm}$ Sephadex G-25 column (Pharmacia Fine Chemicals, Inc., Piscataway, N. J.) in $0.05 \mathrm{M}$ phosphate buffer, $\mathrm{pH} 8.6$, was added (in $25 \mu 1$ ). $25 \mu 1$ of Chloramine- $T$ (Eastman Organic Chemicals Div., Eastman Kodak Co., Rochester, N. Y.) in $0.05 \mathrm{M}$ phosphate buffer (containing $6.2,62$, or $620 \mathrm{~mol}$ of Chloramine-T/mol LDL) were then pipetted into the above mixture, and the reaction was allowed to proceed for $5 \mathrm{~min}$. The reaction mixture was then filtered through a $0.9 \times 30-\mathrm{cm}$ column of Sephadex G-50 equilibrated with $0.05 \mathrm{M}$ barbital buffer, $\mathrm{pH}$ 8.6, $1 \mathrm{mM}$ in EDTA ("barbital buffer"). The first radioactive peak appeared with the void volume, followed by a second peak at or near the "salt" volume. 50 and $<1 \%$ of the label in peaks 1 and 2 were precipitable by $10 \%$ trichloroacetic acid. Peak 1 was diluted with an equal volume of $6 \%$ bovine serum albumin (BSA) in barbital buffer and $1-2 \mathrm{ml}$ aliquots were filtered through a $1.5 \times 30$ $\mathrm{cm}$ column of Sephadex G-200 which had been equilibrated with $3 \%$ BSA and barbital. Three peaks were routinely obtained (Fig. 1). The size of peak 2 varied directly with the amount of Chloramine-T used during iodination and with the age of the preparation. A Chloramine- $T$ concentration of $4.4 \mu \mathrm{g}$ added in $25 \mu \mathrm{l}$ was found to be optimal and was used to obtain the results reported below. The percent precipitability of peaks 1,2 , and 3 by trichloroacetic acid were $75-80,<15$, and $<1$, respectively. Peak 1 


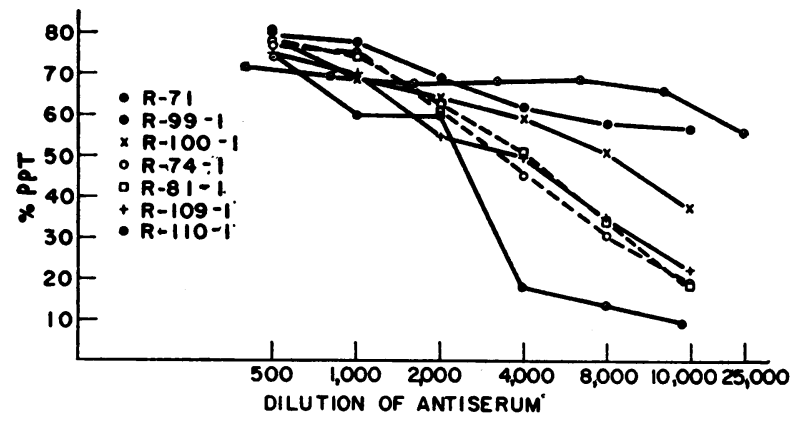

FIgURe 2 Titration curves of anti-LDL and anti-d-LDL (R-109 and R-110). Percent PPT represents the percent of the radioactive LDL precipitated in the assay in the presence of the given amount of cold LDL contained in the sample.

from the G-200 column was refiltered on G-200 and used in the immunoassay ([ $\left.\left.{ }^{125} \mathrm{I}\right] \mathrm{LDL}\right) .\left[{ }^{125} \mathrm{I}\right] \mathrm{LDL}$ was $85-90 \%$ precipitable by trichloroacetic acid and $70-80 \%$ precipitable by anti-LDL; its specific activity was $1.5-3.0 \mu \mathrm{Ci} / \mu \mathrm{g}$. [ [ $\left.{ }^{105} \mathrm{I}\right]-$ LDL was added to $0.5 \mathrm{ml}$ of serum, and the lipids of the serum were extracted by the method of Carlson (26); 93-95\% of the counts remained in the aqueous phase with the proteins. More than $90 \%$ of the counts migrated with the $\beta$-lipoprotein band on agarose gel electrophoresis and more than $85 \%$ floated with LDL in the ultracentrifuge.

The assay. The assay was carried out in test tubes which had been precoated with silicone (Siliclad, Clay Adams Div. of Becton, Dickinson and Co., Parsippany, N. J.) ; all dilutions were made in $3 \%$ BSA in barbital buffer (17). The following additions were made: $100 \mu 1$ of anti-LDL, 8-12,000 $\mathrm{cpm}$ of [ $\left.{ }^{125} \mathrm{I}\right] \mathrm{LDL}$ in $100 \mu 1,5-500$ ng of LDL standard or sample which had been diluted in $3 \%$ BSA-barbital buffer to bring the volume to $500 \mu \mathrm{l}$. After $48 \mathrm{~h}$ of incubation at $4^{\circ} \mathrm{C}, 50 \mu \mathrm{l}$ of goat antirabbit $\gamma$-globulin serum (diluted $1: 4$ ) was added. $24 \mathrm{~h}$ later

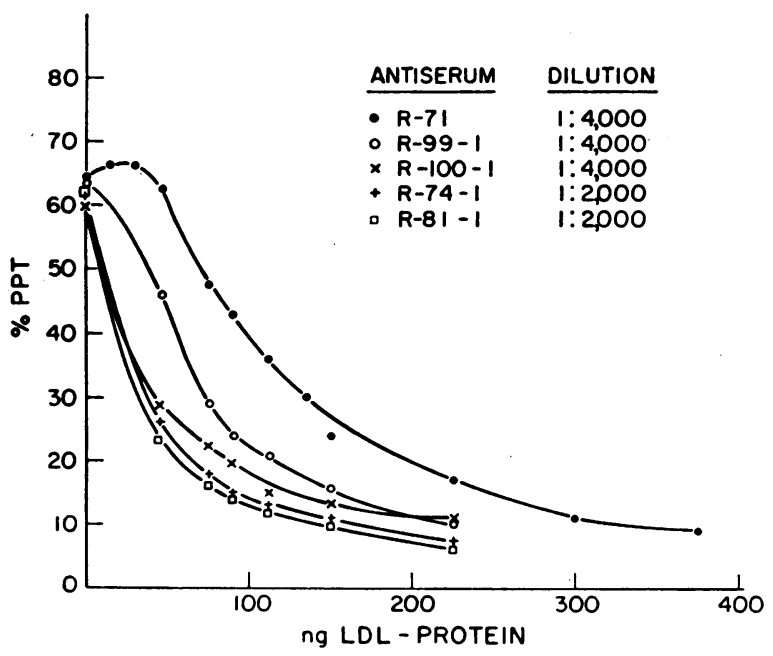

Figure 3 Displacement curves produced by one human LDL preparation with five different anti-LDL antisera. the tubes were centrifuged, the precipitates washed with cold barbital buffer and counted in a Nuclear-Chicago gamma spectrometer (Nuclear-Chicago Corp., Des Plaines, III.). The incubation times were selected to provide maximal precipitability and reproducibility.

Two blanks were included. One contained [ $\left.{ }^{125} \mathrm{I}\right] \mathrm{LDL}$ and buffer to a total volume of $550 \mu 1$. The second contained $100 \mu 1$ of nonimmune rabbit serum in place of anti-LDL and no standard. Both blanks yielded similar counts of $200-250 \mathrm{cpm}$ (less than $5 \%$ of the added radioactivity), which were subtracted from the standard and unknown values.

Source of plasma samples. Patients referred to the M. I. T. Arteriosclerosis Center were bled after an overnight fast. Plasmas were analyzed for triglycerides and total and lipoprotein cholesterol by methods described before (1). Lipoprotein electrophoreses were carried out on paper (27) or agarose (28) (Bio-Rad Laboratories, Richmond, Calif.). Patients were assigned to the various lipoprotein phenotypes $(29,30)$ on the basis of three lipid and electrophoretic analyses carried out under basal conditions. Patients were classified as Type IIa if LDL cholesterol was elevated and plasma triglycerides normal; as Type IIb if LDL cholesterol and plasma triglycerides were both elevated; and as Type IV if LDL cholesterol was normal and plasma triglycerides were elevated, according to published normal limits (4). The results include data obtained from untreated patients as well as from some who were on drug therapy but had not yet shown a therapeutic response, i.e., whose lipids had not changed significantly from control values. Only the Type II subjects were on drug therapy. The Type IV subjects had been treated by weight reduction, while the Type $\mathrm{V}$ subjects were untreated at the time of sampling.

Statistical analyses were performed by Dr. S. Choi of the Division of Biostatistics, Washington University School of Medicine, St. Louis.

\section{RESULTS}

Antisera. Five anti-LDL (R-71, R-74, R-81, R-99, R-100) and two anti-d-LDL antisera (R-109, R-110) were made. All but two were monospecific and yielded one precipitin line on immunoelectrophoresis and immunodiffusion against whole plasma. R-99 and R-100 contained traces of activity against HDL; both were absorbed repeatedly with HDL until no anti-HDL activity was detectable by immunodiffusion.

All antisera precipitated $70-80 \%$ of a preparation of $\left[{ }^{125} \mathrm{I}\right] \mathrm{LDL}$ at dilutions of $1: 500$. Precipitability fell thereafter with increasing dilution. However, $50-60 \%$ of [ ${ }^{125}$ I]LDL was precipitated even at dilutions of $1: 2,000$ $1: 25,000$ (Fig. 2). More than $90 \%$ of the precipitated counts were displaced by "cold" LDL. The affinities of the antisera, manifested by the shapes of the displacement curves, were similar (Fig. 3). ${ }^{2}$ Each of the data points reported in Figs. 2 and 3 represents the mean of two to five determinations; the coefficients of variation ranged from 4.6 to $9.0 \%$ and averaged $8.0 \%$.

${ }^{2}$ Antisera to d-LDL, R-109, and R-110, not shown in Fig. 3, were nearly identical with R-74 and R-81, respectively. 


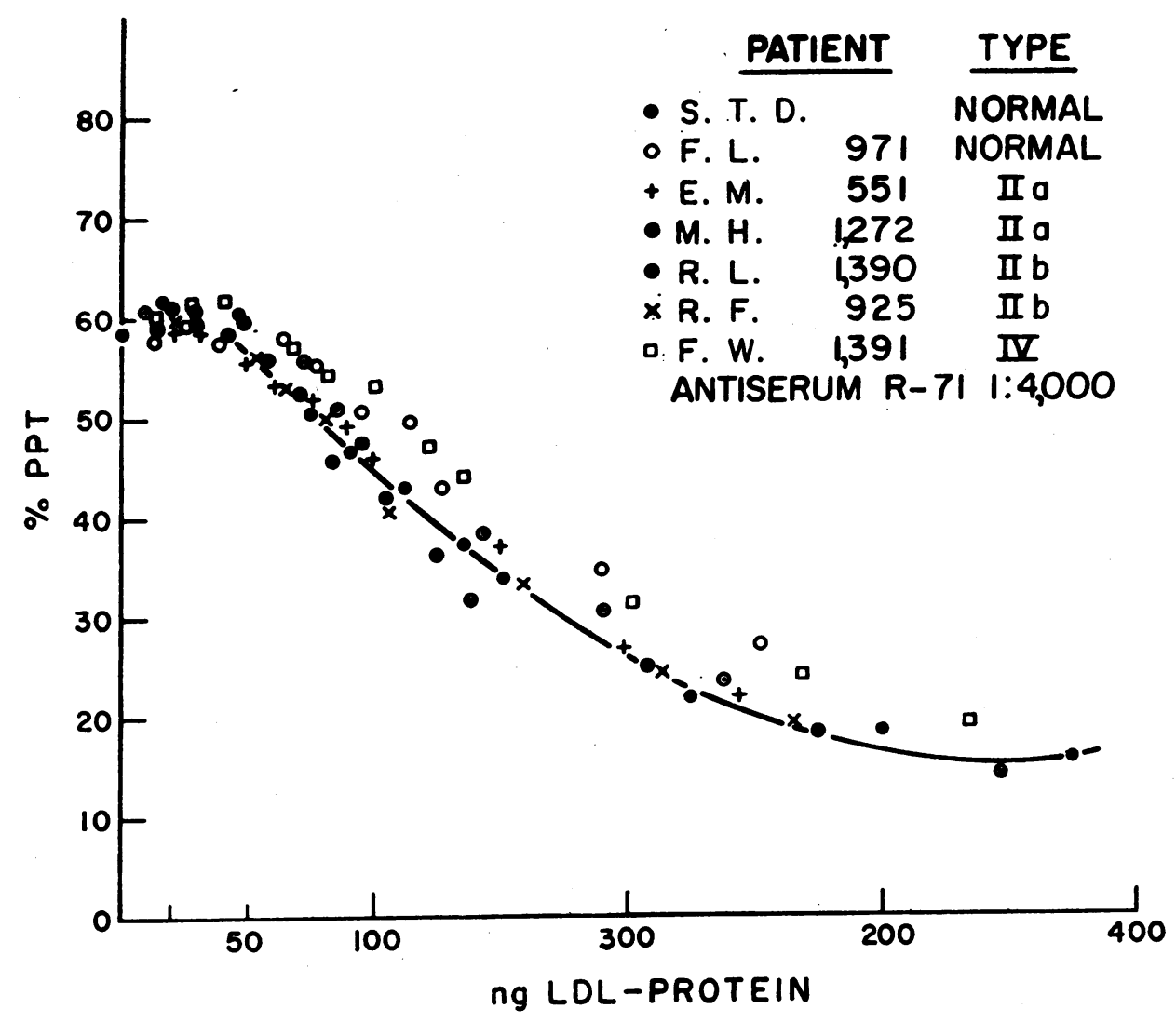

FIGURE 4 Displacement curves produced by seven different human LDL preparations with one antihuman LDL.

Studies with isolated LDL. LDL were isolated between solvent densities of 1.025 and 1.050 from seven subjects (including two normal subjects, four with Type II, and one with Type IV) and assayed in a system containing antiserum R-71 in a $1: 4,000$ dilution. Six other $\mathrm{LDL}$ isolates were compared to each other in a more sensitive assay system utilizing $\mathrm{R}-71$ antiserum in a $1: 25,000$ dilution. A third set of six LDL preparations were isolated, two each from Type II, Type IV, and normal subjects. These were assayed by utilizing antiserum R-99 at 1:4,000 dilution. The LDL preparations within each set yielded displacement curves which were parallel with each other.

Some minor differences between the LDLs were noted, however (Fig. 4). For any given amount of protein added to the assay, somewhat more counts were displaced by some of the LDLs than by others, suggesting either that the antigenicity of LDL varied from patient to patient or that there was protein in some of the LDĹs which was not "recognized" by the anti-LDL antiserum. In spite of these differences, the agreement between the RIA and Lowry procedures was close $(r=$
$0.94, n=19$ ), suggesting that antigenic variation or "nonrecognized" protein was not a significant hindrance in using the RIA for the quantitation of ApoB.

Studies with isolated and purified $\mathrm{d}<1.006$ lymph and plasma lipoproteins. Chylomicrons obtained from one subject with chylous ascites and one subject with an indwelling thoracic duct cannula were isolated and purified by repeated ultracentrifugation at $d=1.006$ for $3 \times 10^{\circ} \mathrm{g} / \mathrm{min}$. Plasma chylomicrons were isolated in a similar fashion from the plasma of a Type V subject 6 $\mathrm{h}$ after the oral ingestion of $150 \mathrm{~g}$ of corn oil. Albumin and nonlipoprotein globulins were not detectable by immunodiffusion in these preparations. When added to the assay, the lymph and plasma chylomicrons produced displacement curves which paralleled those of the LDL standard.

Blood was drawn from 17 fasting normal subjects, from 2 Type II, 5 Type IV, and 2 Type V subjects. VLDL (VLDL plus chylomicrons for the Type V subjects) were isolated by repeated ultracentrifugation at $d=1.006$. Aliquots of these samples were added to the assay; all but one produced displacement curves which 
TABLE I

ApoB Contents of Chylomicrons and VLDL as Determined by RIA and by Column Chromatography*

\begin{tabular}{cccc}
\hline & \multicolumn{3}{c}{$\begin{array}{c}\text { ApoB as percent of total } \\
\text { apolipoprotein }\end{array}$} \\
\cline { 2 - 4 } & $\begin{array}{c}\text { OD 280 } \\
\text { nm }\end{array}$ & $\begin{array}{c}\text { Colori- } \\
\text { metric }\end{array}$ & RIA \\
\hline Plasma chylomicrons & 21 & 20 & 24 \\
Plasma VLDL 1 & 28 & 29 & 32 \\
2 & 23 & 29 & 29 \\
\hline
\end{tabular}

OD $280 \mathrm{~nm}=$ area of first peak/total protein $\times 100$. RIA $=$ ApoB $(\mathrm{RIA}) /$ total protein $\times 100$. Total Protein $=\mathrm{SF}_{1}$ (Lowry protein $\times 0.77$ ) $+\mathrm{SF}_{3}$ (Lowry protein $\times 0.85$ ). Colorimetric $=\mathrm{SF}_{1}($ Lowry protein $\times 0.77) /$ Total protein.

* VLDL and Chylomicrons were delipidated, peptides were solubilized and filtered on Sephadex G-150 according to Brown et al. (10). Fractions were monitored at $280 \mathrm{~nm}$. Areas under the curve were determined by planimetry.

paralleled the standard curve (Fig. 5). One VLDLchylomicron preparation from a Type V subject produced a slightly flatter displacement curve.

Reactivity of $H D L$. Two HDL samples ( $d=1.090$ 1.21) were assayed. $10 \mu \mathrm{g}$ of protein failed to displace any counts. 50 and $100 \mu \mathrm{g}$ displaced some counts, suggesting that less than $0.2 \%$ of the total $\mathrm{HDL}$ protein was comprised of ApoB protein.

Reactivity of abetalipoproteinemic plasma. When as much as $200 \mu 1$ of plasma from an abetalipoproteinemic subject was added to the assay system, representing an 8,000 -fold excess over the plasma concentration ordinarily used, no displacement of counts was obtained.

The ApoB content of VLDL and chylomicrons. To assess the ApoB content of VLDL and chylomicrons, two preparations of plasma VLDL and one of plasma chylomicrons were delipidated. The apolipoproteins were solubilized and chromatographed on columns of Sephadex G-150, according to Brown, Levy, and Fredrickson

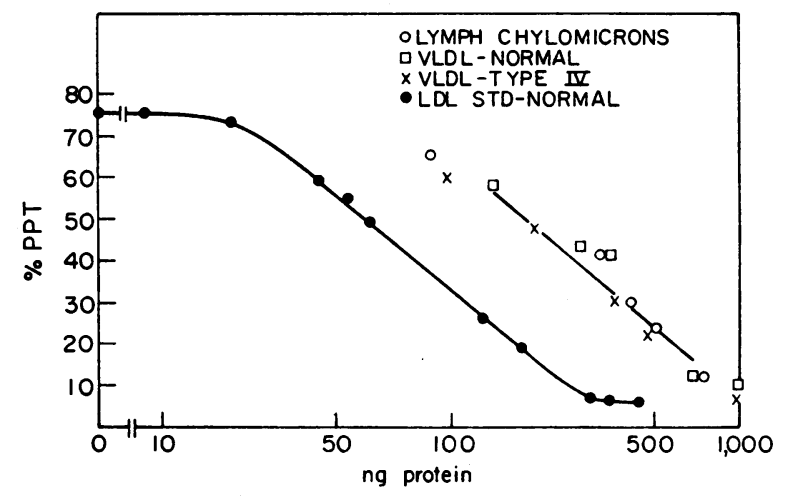

FIgURE 5 Displacement curves of chylomicrons and VLDL compared with that of an LDL standard.
(10). Column recoveries of protein were 92-95\%. Two peaks, corresponding to the $\mathrm{SF}_{1}$ and $\mathrm{SF}_{3}$ fractions of Brown, were routinely obtained. $\mathrm{SF}_{2}$ usually consisted of a broad baseline elevation between $\mathrm{SF}_{1}$ and $\mathrm{SF}_{\mathbf{3}} \mathrm{SF}_{1}$ reacted with anti-LDL but not with anti-HDL or antiapolipoprotein $\mathrm{C}$ by immunodiffusion. $\mathrm{SF}_{2}$ and $\mathrm{SF}_{\mathbf{3}}$ did not react with anti-LDL. $\mathrm{SF}_{1}$ was therefore considered to be composed primarily of $A p o B$ and to be the only peak which contained appreciable amounts of ApoB, as has been reported by others (31). The protein contents of the column eluates were determined by the Lowry method. In addition, the areas under each of the chromatographic peaks were obtained by planimetry. $\mathrm{SF}_{1}$ appeared to represent $20-30 \%$ of total apolipoproteins. The ApoB contents of these chylomicrons and VLDL were also determined by RIA of the original nondelipidated preparation. The results obtained by the immunologic and chromatographic procedures were in good agreement (Table I).

The ApoB contents of another three plasma VLDL, two lymph, and one plasma chylomicron preparations were asessed by the RIA. Total apolipoproteins were determined by the method of Lowry (22). ApoB appeared to represent about $25 \%(20,24,27 \%)$ and $35 \%$ $(29,32,42 \%)$ of the total apolipoproteins of chylomicrons and VLDL, respectively.

Comparison of the radial immunodiffusion and radioimmunoassays. $83 d>1.006$ plasma infranates were assayed by both radioimmunoassay and by radial immunodiffusion (16). The correlation coefficient between the results obtained by the two methods was 0.92 .

Assay of plasma. The ApoB contents of whole plasma, and of $d=1.006$ infranates and supernates were determined in four-point assays. Intra-assay coefficients of variation ranged from 6.4 to $11 \%$ and averaged $9 \%$.

The assay was accurate to $\pm 10 \%$ with as little as 30 ng of ApoB at a 1:4,000 dilution of anti-LDL (R-71) (32). However, as little as $5 \mathrm{ng}$ of ApoB could be measured with that precision when the antiserum was diluted $1: 25,000$.

Whole plasma, $d<1.006$ and $d>1.006$ fractions were analyzed in 19 samples whose total ApoB concentrations ranged from 98 to $313 \mathrm{mg} / \mathrm{dl}$. The ApoB content (x) of whole plasma was $167 \pm 86$ (mean $\pm \mathrm{SD}$ in $\mathrm{mg} / \mathrm{dl}$ ); the ApoB-protein concentration of the sums of the $d=1.006$ super- and infranates (y) was $156 \pm 96$, and the correlation of $(y)$ on $(x)$ was 0.92 . Because of this close agreement, the ApoB content of the plasma fractions of $d<1.006$ was obtained in most patients by difference between the values for whole plasma and for the fraction of $d>1.006$.

Plasma ApoB-protein and lipid values of normal and hyperlipoproteinemic subjects are listed in Table II. The mean fasting total plasma ApoB level of a group 
TABLE II

Plasma ApoB Levels in Hyperlipoproteinemia

\begin{tabular}{|c|c|c|c|c|c|c|c|c|c|c|c|}
\hline \multirow{3}{*}{$\begin{array}{r}\text { Lipoprotein } \\
\text { phenotypes }\end{array}$} & \multirow{2}{*}{\multicolumn{3}{|c|}{ ApoB by radioimmunoassay }} & \multicolumn{2}{|c|}{ ApoB ratios } & \multirow{3}{*}{$\begin{array}{c}\text { Immuno } \\
\text { diffusion } \\
\text { LDL-protein }\end{array}$} & \multirow{2}{*}{\multicolumn{2}{|c|}{ Plasma lipids }} & \multirow{2}{*}{\multicolumn{3}{|c|}{ Lipoprotein cholesterol $\neq$}} \\
\hline & & & & & & & & & & & \\
\hline & Total & VLDL* & LDL* & Total & Total & & TG & TC & $\mathrm{VLDL} \cdot \mathrm{C}$ & $\mathrm{LDL} \cdot \mathrm{C}$ & $\mathrm{HDL} \cdot \mathrm{C}$ \\
\hline \multirow[t]{2}{*}{ Normal } & 83 & 5 & 83 & 0.05 & 0.94 & 87 & 104 & 213 & 32 & 167 & 35 \\
\hline & $\pm 16(42)$ & $6(17)$ & $17(17)$ & 0.06 & 0.06 & 27 (14) & 29 (14) & $39(42)$ & $8(17)$ & 18 (17) & 7 (17) \\
\hline \multirow[t]{2}{*}{ II } & $162 \S$ & 13 & 1458 & 0.09 & 0.93 & 1528 & 145 & $350 \S$ & 35 & 279 & 36 \\
\hline & $52(27)$ & $15(22)$ & $57(22)$ & 0.09 & 0.10 & $52(22)$ & $60(27)$ & $65(27)$ & $19(22)$ & $68(22)$ & $8(22)$ \\
\hline \multirow[t]{2}{*}{ IV } & $112 \S$ & $21 \S$ & 89 & $0.16 \S$ & $0.81 \S$ & 80 & 3168 & 227 & $62 \S$ & 140 & 28 \\
\hline & $24(43)$ & $16(26)$ & $17(24)$ & 0.12 & 0.13 & $19(24)$ & $126(43)$ & $32(43)$ & $36(26)$ & 27 (24) & 7 (24) \\
\hline \multirow[t]{2}{*}{ V } & $105 \S$ & $42 \S$ & $53 \S$ & $0.41 \S$ & $0.49 \S$ & 608 & 2,1168 & 250 & $164 \S$ & 678 & $18 \S$ \\
\hline & $17(4)$ & $6(4)$ & $22(4)$ & 0.12 & 0.15 & $14(4)$ & $1,666(4)$ & $24(4)$ & $64(4)$ & $42(4)$ & $8(4)$ \\
\hline
\end{tabular}

Results expressed as mean tone S.D. in $\mathrm{mg} / \mathrm{dl}$. ( ) = number of subjects. TG is triglycerides and TC is total cholesterol.

$*$ VLDL $=$ ApoB content of $d<1.006$ and LDL $=$ ApoB content of $d>1.006$ fractions of plasma.

¥ Lipoprotein cholesterol determined on fractions isolated by ultracentrifugation and precipitation (1).

Significantly different from normal $(P \leq 0.02)$.

of normal subjects of mean age $42 \pm 13$ yr was $83 \pm 16$ $\mathrm{mg} / \mathrm{dl}$. Mean levels were highest in Type II hyperlipoproteinemia ( $162 \mathrm{mg} / \mathrm{dl}$ ), but were also elevated in Types IV and V. In these patients, levels of lipids and of LDL-protein by radial immunodiffusion (Table III) were similar to those reported previously (16).

Plasmas of several subjects whose plasma lipids were stable on constant dietary and/or drug regimens were assayed repeatedly for fasting total ApoB levels. These varied little over weeks to months (Table III).

Patients with Type II hyperlipoproteinemia have recently been divided into two subgroups (30). $\mathrm{Pa}$ -

TABLE III

Constancy of Plasma ApoB Levels Over Time

\begin{tabular}{lrrrr}
\hline \multicolumn{1}{c}{ Patient } & $\begin{array}{c}\text { Date of } \\
\text { sample }\end{array}$ & TG* & TC* & ApoB $¥$ \\
\hline & & & $m g / d l$ & \\
L. D. & $2 / 22 / 72$ & 116 & 256 & 92 \\
Type IV & $3 / 20 / 72$ & 96 & 229 & 97 \\
& $4 / 04 / 72$ & 117 & 222 & 87 \\
& $4 / 10 / 72$ & 100 & 263 & 92 \\
L. B. & $2 / 29 / 72$ & 237 & 250 & 83 \\
Type IV & $3 / 21 / 72$ & 222 & 241 & 91 \\
L. M. & $5 / 01 / 72$ & 149 & 233 & 102 \\
Type IV & $5 / 15 / 72$ & 143 & 232 & 117 \\
J. H. & $2 / 15 / 72$ & 192 & 429 & 151 \\
Type IIb & $2 / 22 / 72$ & 228 & 407 & 143 \\
& $5 / 02 / 72$ & 166 & 452 & 179 \\
L. R. & $4 / 25 / 72$ & 203 & 420 & 146 \\
Type IIb & $5 / 01 / 72$ & 287 & 407 & 150 \\
& $5 / 08 / 72$ & 212 & 438 & 185 \\
\hline
\end{tabular}

See Table II for abbreviations.

* Triglycerides and total cholesterol were determined on the Technicon Auto Analyzer I (Technicon Instruments Corp., Tarrytown, N. Y.) (1).

$\ddagger$ ApoB was assayed by the radioimmunoassay. tients with elevated levels of total cholesterol and/or LDL cholesterol and normal triglyceride concentrations have been classified as IIa ; those with high total cholesterol and/or LDL cholesterol levels and high triglyceride concentrations are called IIb. 19 of our patients were IIa (mean triglyceride and total cholesterol were 115 and 333, respectively) and 8 were IIb (mean triglyceride $=220$, mean total cholesterol $=369$ ). The mean total ApoB levels of these two groups did not significantly differ from each other (IIa $=165 \mathrm{mg} / \mathrm{dl}$, $\mathrm{IIb}=155 \mathrm{mg} / \mathrm{dl}$ ).

The values of total plasma $A p o B$ in normal subjects were normally distributed, and there was little overlap between the Type II and normal populations. By contrast, about $60 \%$ of the Type IV subjects had levels of total ApoB which overlapped with those of the normals (Fig. 6). The distribution of the values of $A$ poB or of the logs of these values in Type IV was not normal. There was significant skewness to the right (for ApoB,

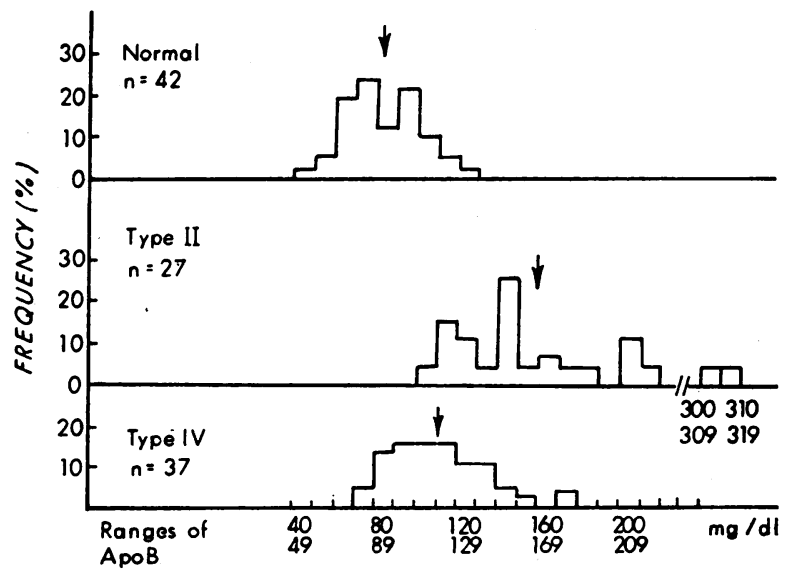

Figure 6 Frequency distribution of ApoB levels in normals and Types II and IV hyperlipoproteinemia. 


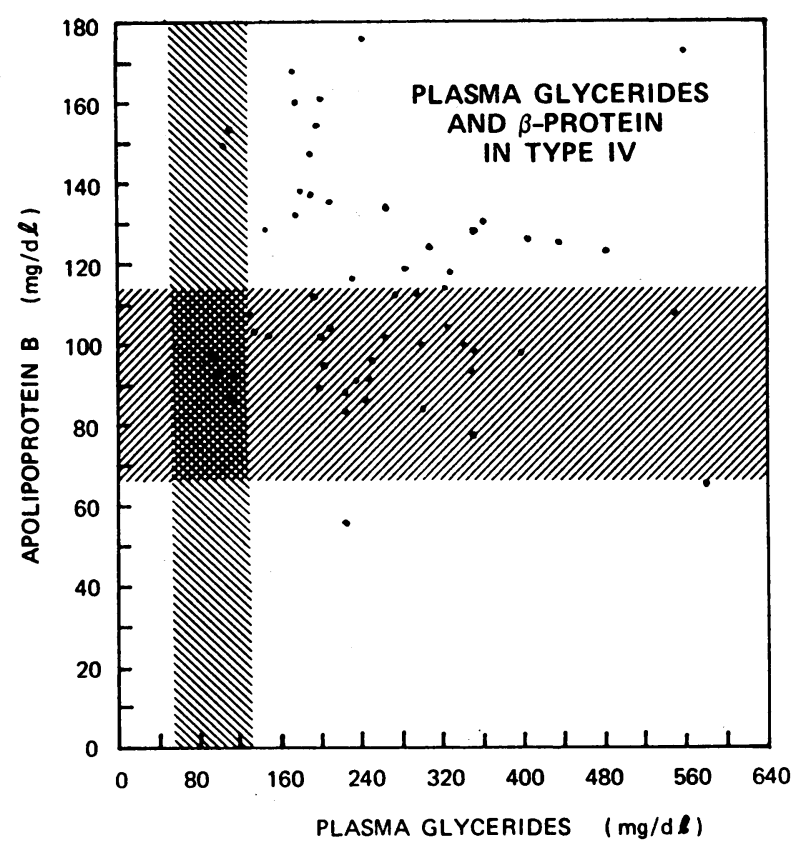

Figure 7 The relationship of plasma ApoB concentrations in Type IV to plasma glyceride concentrations. Some patients are included who have been treated to normal glyceride levels with diet alone.

skewness $=+0.8, \quad P<0.05$, kurtosis $=0.47, \quad P>0.1$; for $\log \mathrm{ApoB}$, skewness $=+0.257, P<0.1$, kurtosis $=$ $2.31, P>0.1$ ). It was not possible to ascertain on the basis of plasma ApoB concentrations alone whether or not this distribution represented two distinct subpopulations of Type IV subjects. However, when plasma $\mathrm{ApoB}$ concentration was graphed against plasma glycerides (Fig. 7), two subgroups with little overlap became apparent.

An estimate of the average load of cholesterol and glycerides carried by the total $\mathrm{ApoB}$ circulating in plasma was obtained by calculation of lipid/ApoB ratios (Table IV). About $2 \mathrm{mg}$ of cholesterol was carried by each mg of ApoB (column 1); however, normal subjects differed significantly from those with Types II and IV. Although the amount of triglyceride carried per milligram of ApoB was much more variable, here too, there were differences between normal and hyperlipoproteinemic subjects. As reported previously (16), there were also differences in LDL cholesterol/LDL ApoB ratios. The correlations (Table $\mathrm{V}$ ) between lipid and ApoB levels in whole plasma and in the $d<1.006$ and $d>1.006$ fractions were unique for each phenotype. These data confirm our earlier impression (16) that the quantitative relationship of lipids to apolipoproteins are altered in hyperlipoproteinemia.

Cross-reactivity between human and animal $A p o B$. Plasmas of several species of animals were added to the
RIA to assess the usefulness of the assay using human LDL and antihuman LDL for measuring the plasma ApoB levels of some of the commonly available laboratory animals. Useful displacement curves were not obtained.

\section{DISCUSSION}

The assay and immunologic studies of plasma fractions. ApoB plays an essential role in the secretion of triglyceride-rich lipoproteins from liver and from gut (1). It has been identified in several of the lipoproteins of plasma, including chylomicrons (33), VLDL (10, $11,31)$, LDL (31), Lp $x$ (34), and $L_{p}(a)$ (35). In spite of its obvious importance, it has not been possible in the past to estimate the total $\mathrm{ApoB}$ content of plasma in man directly. The ApoB contents of $d>1.006$ fractions can be assessed by radial immunodiffusion (16), but the ApoB content of $d<1.006$ fractions has to be obtained by applying gel chromatography to peptides isolated from $d<1.006$ supernates $(10,11,31)$, a lengthy and laborious procedure. The radial immunodiffusion technique is suitable for clinical laboratory use and has yielded valuable results $(16,36)$. However, a procedure was needed which would allow the quantification of ApoB in whole plasma as well as in plasma fractions and individual lipoprotein classes. The double antibody RIA appears to meet these requirements: $(a)$ the assay appears to be highly specific. ApoB-containing lipoproteins, i.e., chylomicrons and VLDL, $d<1.006$ and $d>1.006$ plasma fractions, and whole plasma each produced displacement curves which paralleled those produced by LDL standards. Thus, ApoB-containing fractions, whether from normal or hyperlipoproteinemic subjects, reacted identically with LDL in the assay, while HDL and abetalipoproteinemic plasma did not react; (b) the precision of the LDL-RIA is comparable with that of other radioimmunoassays (37). Samples appear to be stable for about 4 wk at $4^{\circ} \mathrm{C}$ (freezing appears to change the displacement characteristics of plasma; the effect of this on numerical values for $A$ poB concentration has not been determined); (c) results obtained by RIA compared well with those obtained by other means. ApoB contents of $d>1.006$ fractions by RIA correlated strongly with results obtained by radial immunodiffusion $(r=0.92)$; LDL-protein by Lowry and by RIA were also in good agreement $(r=0.94)$. The ApoB content of $d<1.006$ fractions by RIA and by gel chromatography also agreed closely (Table I). Thus, the RIA was able to measure the ApoB contents of the $d<1.006$ and $d>1.006$ fractions of plasma with some accuracy. The sensitivity of the assay to as little as $5 \mathrm{ng}$ of $\mathrm{ApoB}$ was in excess of that needed for assaying plasma $A$ poB ; for routine use, sensitivity was scaled down (to about $30 \mathrm{ng}$ ) by altering the dilution of the 
anti-LDL antiserum. The potential for greater sensitivity may be very useful, however, in studies where sample size is limited, e.g., in infants or in vitro studies.

The finding of immunologic identity among the chylomicron, VLDL, and LDL ApoB's suggests that the ApoB found in the various lipoproteins of plasma represents the same protein. The finding of immunologic identity also suggested that the ApoB's of normal and hyperlipoproteinemic subjects were identical. Gotto, Brown, Levy, Birnbaumer, and Fredrickson (31) have recently presented similar evidence and have reached the same conclusions. The exact structure of ApoB and the number and size of its structural units is still unknown. Lee and Alaupovic (38) have isolated two LDL subfractions of $d-1.030-1.040 \mathrm{~g} / \mathrm{ml}$ and $1.040-1.053 \mathrm{~g} / \mathrm{ml}$, which differed immunologically and by amino acid composition, but had the same beta mobility on electrophoresis. The minor differences seen and noted in the Results section as "nonrecognized" protein may represent heterogeneity in the structure of LDL-protein as well as the presence of small amounts of apolipoproteins other than ApoB, as has been reported by others $(11,15,38)$.

A good deal of data exists which suggests that VLDL are degraded to LDL in plasma by sequential glyceride removal steps resulting in gradual diminution in average size (39-41). LDL, in turn, are removed from plasma at sites which to date have not been identified. The various hyperlipoproteinemias are thought to represent blocks at different points along the catabolic pathways of VLDL (Types III, IV, and perhaps V) or LDL (Type II). More than $90 \%$ of the total ApoB in our experiments was in the $d=1.006$ infranates of plasma in normal and Type II subjects, whereas in Types IV and $\mathrm{V}, 20-50 \%$ of the total was in the $d=1.006$ supernates. This evidence suggests that the ApoB content of the plasma and the fraction in each lipoprotein density class together gives an indication of the presence and position of a block in the normal sequence of lipoprotein catabolism.

Since the composition of each of the density classes of lipoproteins is unique $(1,42)$, a block in lipoprotein
TABLE IV

Ratios of Lipid to ApoB in Hyperlipoproteinemia

\begin{tabular}{ccccc}
\hline $\begin{array}{c}\text { Lipoprotein } \\
\text { phenotype }\end{array}$ & TC-HDL.C & TG & LDL.C & VLDL·C \\
\cline { 5 - 5 } & Total ApoB & Total ApoB & $\frac{\text { LDL·ApoB }}{\text { LDLD }}$ & VLDoB \\
\hline Normal & $2.48^{*}$ & 1.29 & 2.04 & 13.40 \\
(42) & \pm 0.54 & 0.41 & 0.32 & 9.01 \\
II & $2.09 \ddagger$ & $0.97 \ddagger$ & 2.04 & 12.02 \\
$(24)$ & 0.46 & 0.42 & 0.39 & 12.58 \\
IV & $1.94 \ddagger$ & $2.89 \ddagger$ & $1.61 \ddagger$ & 8.27 \\
$(37)$ & 0.40 & 1.32 & 0.25 & 10.99 \\
V & 2.26 & $21.7 \ddagger$ & $1.22 \ddagger$ & 3.29 \\
$(4)$ & 0.54 & 17.7 & 0.45 & 1.36 \\
\hline
\end{tabular}

See Table II for abbreviations. TC-HDL $\cdot \mathrm{C}=$ total cholesterol minus HDL cholesterol, i.e., cholesterol content of VLDL plus LDL.

* Mean tone SD, ( ) = number of subjects.

$\ddagger$ Significantly different from normal $(P \leq 0.02)$.

catabolism which resulted in the accumulation in plasma, in abnormal concentration, of lipoproteins of different sizes and densities would result in altered ratios of the plasma lipids to ApoB. That this was the case in the various hyperlipoproteinemias is shown in Table IV.

Plasma $A$ poB levels. The mean total ApoB level of normal subjects was $83 \pm 16 \mathrm{mg} / \mathrm{dl}$, a value similar, as might be expected, to that obtained for LDL-protein in normal subjects (16). Mean levels were twice normal in Type II; lesser increases occurred in subjects with Types IV and V. There was relatively little overlap between Type II and normal subjects, and, as compared with the estimation of LDL-protein by radial immunodiffusion (16), assay of total plasma ApoB by RIA provided a somewhat better differentiation of Type II from normal subjects.

Type IV subjects, with similar triglyceride and total cholesterol levels, may have either elevated or normal total ApoB levels, and the distribution of $A$ poB was skewed to the right.

$A$ poB concentration alone was insufficient to define two populations within the Type IV group. When ApoB was graphed against plasma glycerides (Fig. 7), it became clear that there was no correlation between these two parameters. It is tempting to hypothesize that the

TABLE V

Correlations of $A p o B$ and Lipid Levels

\begin{tabular}{|c|c|c|c|c|c|c|c|c|c|c|c|c|}
\hline \multirow{2}{*}{$\begin{array}{l}\text { Lipoprotein } \\
\text { phenotypes }\end{array}$} & \multicolumn{4}{|c|}{ Total ApoB vs. } & \multicolumn{4}{|c|}{ VLDL-ApoB vs. } & \multicolumn{4}{|c|}{ LDL-ApoB vs. } \\
\hline & TG & TC & VLDL $\cdot C$ & $\mathrm{LDL} \cdot \mathrm{C}$ & TG & TC & VLDL $\cdot C$ & $\mathrm{LDL} \cdot \mathrm{C}$ & TG & $\mathrm{TC}$ & $\mathrm{VLDL} \cdot \mathrm{C}$ & $\mathrm{LDL} \cdot \mathrm{C}$ \\
\hline Normal & $0.36^{*}$ & $0.39 *$ & $0.66 \ddagger$ & 0.22 & $0.47 *$ & -0.11 & 0.09 & -0.02 & 0.32 & $0.43^{*}$ & $0.68 \ddagger$ & 0.26 \\
\hline Type II & 0.01 & $0.67 \S$ & -0.19 & $0.75 \S$ & 0.27 & -0.03 & -0.15 & 0.00 & 0.00 & $0.75 \S$ & -0.13 & $0.80 t$ \\
\hline Type IV & $0.40^{*}$ & $0.39 *$ & 0.18 & 0.28 & 0.688 & 0.25 & $0.47 \ddagger$ & -0.24 & -0.03 & 0.21 & -0.32 & 0.668 \\
\hline All & -0.04 & 0.688 & -0.10 & $0.72 \S$ & 0.658 & -0.02 & 0.608 & -0.30 & -0.29 & 0.798 & -0.35 & $0.80 \S$ \\
\hline
\end{tabular}

See Table II for abbreviations.

$* P<0.05$.

$\ddagger P<0.01$.

$\S P<0.001$. 
patients with high ApoB concentration might represent those with the recently described "combined hyperlipidemia $(43,44)$, while those subjects with relatively low ApoB concentrations and high triglycerides have the dominantly inherited hypertriglyceridemia previously described $(4,29,30,45,46)$. We suggest in any case that the use of quantitative assays of plasma apolipoprotein concentration in genetic studies of the hyperlipidemias will inevitably prove superior to qualitative techniques for resolution of the inheritance of these common and clinically important syndromes.

\section{ACKNOWLEDGMENTS}

We are grateful to Dr. Margaret P. Rogers for her help in lipoprotein characterization and to Mr. Gene DiBenedetto and his staff for the lipid analyses.

This work was supported in part by grants from the General Clinical Research Centers Program of the Division of Research Resources, NIH (RR88), by the Arteriosclerosis Centers Program of the National Heart and Lung Institute (HL14209), and by research grants from the Lillia Babbitt Hyde Foundation, the National Dairy Council (108) and the National Heart and Lung Institute (HL12621).

\section{REFERENCES}

1. Hatch, F. T., and R. S. Lees. 1968. Practical methods for plasma lipoprotein analysis. Adv. Lipid Res. 6: 1.

2. Alaupovic, P., G. Kostner, D. M. Lee, W. J. McConathy, and H. N. Magnani. 1972. Peptide composition of human plasma apolipoproteins A, B, and C. Expo. Annu. Biochim. Med. 31: 145.

3. Scanu, A. M., and C. Wisdom. 1972. Serum lipoproteins: structure and function. Annu. Rev. Biochem. 41: 703 .

4. Fredrickson, D. S., R. I. Levy, and R. S. Lees. 1967. Fat transport in lipoproteins-an integrated approach to mechanisms and disorders. N. Engl. J. Med. 276: 215.

5. Reaven, G. M., D. B. Hill, R. C. Gross, J. W. Farquar, and E. P. Brown. 1965. Kinetics of triglyceride turnover of very low density lipoproteins of human plasma. J. Clin. Invest. 44: 1826.

6. Goodman, D. S., and R. P. Noble. 1968. Turnover of plasma cholesterol in man. J. Clin. Invest. 47: 231.

7. Nikkila, E. A., and M. Kekki. 1971. Measurement of plasma triglyceride turnover in the study of hyperglyceridemia. Scand. J. Clin. Lab. Invest. 27: 97.

8. Hurley, P. J., and P. J. Scott. 1970. Plasma turnover of $\mathrm{S}_{\mathrm{f}} \mathrm{O9}$ low-density lipoprotein in normal men and women. Atherosclerosis. $11: 51$.

9. Eaton, R. P., and D. M. Kipnis. 1972. Incorporation of $\mathrm{Se}^{7 \mathrm{t}}$ Selenomethionine into a protein component of plasma very-low-density lipoprotein in man. Diabetes. $21: 744$.

10. Brown, W. V., R. I. Levy, and D. S. Fredrickson. 1969. Studies of the proteins in human plasma very low density lipoproteins. J. Biol. Chem. 244: 5687.

11. Shore, B., and V. Shore. 1969. Isolation and characterization of polypeptides of human serum lipoproteins. Biochemistry. 8: 4510.
12. Scanu, A., J. Toth, C. Edelstein, S. Koga, and E. Stiller. 1969. Fractionation of human serum high density lipoprotein in urea solutions. Evidence for polypeptide heterogeneity. Biochemistry. 8: 3309.

13. Rudman, D., L. A. Garcia, and C. H. Howard. 1970. A new method for isolating the nonidentical protein subunits of human plasma $\alpha$-lipoprotein. J. Clin. Invest. $49: 365$.

14. Gotto, A. M., Jr. 1969. Recent studies on the structure of human serum low- and high-density lipoproteins. Proc. Natl. Acad. Sci. U. S. A. 64: 1119.

15. Kane, J. P., E. G. Richards, and R. J. Havel. 1970. Subunit heterogeneity in human serum beta lipoprotein. Proc. Natl. Acad. Sci. U. S. A. 66: 1075.

16. Lees, R. S. 1970. Immunoassay of plasma low-density lipoprotein. Science (Wash. D. C.). 169: 493.

17. Eaton, R. P., and D. M. Kipnis. 1969. Radioimmunoassay of beta lipoprotein-protein in rat serum. $J$. Clin. Invest. 48 : 1387.

18. Birnbaumer, M. E., R. I. Levy, and A. M. Gotto. 1971. Radioimmunoassay of human low density lipoprotein-protein. Circulation. 44 (Suppl. 2) : 141.

19. Ritchie, R. F., and C. Clark. 1972. An attempt at classification of the diseases of human lipoproteins by automated techniques. Technicon International Symposium Automation in Clinical Chemistry. Mediaid Inc. New York. 25.

20. Kahan, J., and L. Sundblad. 1969. Immunochemical determination of $\beta$-lipoproteins. Scand. J. Clin. Invest. 24: 61 .

21. Schonfeld, G., B. Pfleger, and R. S. Lees. 1972. Plasma $\beta$-protein in the classification of the hyperlipidemias. Circulation. 46 (Supp1. 2) : 17.

22. Lowry, O. H., N. J. Rosebrough, A. L. Farr, and R. J. Randall. 1951. Protein measurement with the Folin phenol reagent. J. Biol. Chem. 193 : 165.

23. Margolis, S., and R. G. Langdon. 1966. Studies of human serum $\beta$-lipoproteins: I. Amino acid composition. J. Biol. Chem. 241: 469.

24. Williams, C. A., and M. W. Chase. 1967. Meth. Immunol. Immunochem. 1: 321.

25. Greenwood, F. G., W. M. Hunter, and J. S. Glover. 1963. The preparation of ${ }^{130} \mathrm{I}$-labelled human growth hormone of high specific radioactivity. Biochem. J. 89: 114.

26. Carlson, L. A. 1963. Determination of serum triglycerides. J. Atheroscler. Res. $3: 334$.

27. Lees, R. S., and F. T. Hatch. 1963. Sharper separation of lipoprotein species by paper electrophoresis in albumin-containing buffer. J. Lab. Clin. Med. 61: 518 .

28. Noble, R. P. 1968. Electrophoretic separation of plasma lipoproteins in agarose gel. J. Lipid Res. 9: 693.

29. Fredrickson, D. S., and R. S. Lees. 1965. A system for phenotyping hyperlipoproteinemia. Circulation. 31: 321.

30. Beaumont, J. L., L. A. Carlson, G. R. Cooper, Z. Fejfar, D. S. Fredrickson, and T. Strasser. 1970. Classification of hyperlipidemias and hyperlipoproteinemias. Bull.W. H. O. $43: 891$.

31. Gotto, A. M., W. V. Brown, R. I. Levy, M. E. Birnbaumer, and D. S. Fredrickson. 1972. Evidence for the identity of the major apoprotein in low density and very low density lipoproteins in normal subjects and patients with familial hyperlipoproteinemia. J. Clin. Invest. $51: 1486$. 
32. Midgley, A. R., Jr., G. D. Niswender, and R. W. Rebar. 1969. Principles for the assessment of the reliability of radioimmunoassay methods. (Precision, accuracy, sensitivity, specificity). Acta. Endocrinol. Suppl. 142: 163

33. Kostner, G., and A. Holasek. 1972. Characterization and quantification of the apolipoproteins from human chyle chylomicrons. Biochemistry. 2: 1217.

34. Seidel, D., P. Alaupovic, R. H. Furman, and W. J. McConathy. 1970. A lipoprotein characterizing obstructive jaundice. II. Isolation and partial characterization of the protein moieties of low density lipoproteins. $J$. Clin. Invest. 49 : 2396.

35. Ehnholm, C., H. Garoff, O. Renkonen, and K. Simons. 1972. Protein and carbohydrate composition of $\operatorname{Lp}(\mathrm{a})$ lipoprotein from human plasma. Biochemistry. 11: 3229.

36. Wilson, D. E., and R. S. Lees. 1972. Metabolic relationships among the plasma lipoproteins. Reciprocal changes in the concentrations of very low density lipoproteins in man. J. Clin. Invest. 51: 1051.

37. Yalow, R. S., and S. A. Berson. 1968. General principles of radioimmunoassay. In Radioisotopes in Medicine in vitro Studies. R. L. Hayes, F. R. Goswitz, and B. E. P. Murphy, editors. Oak Ridge Institute Nuclear Studies, United States Atomic Energy Commission, Office of Information Services, Oak Ridge, Tenn. 7.

38. Lee, D. M., and P. Alaupovic. 1970. Studies of the composition and structure of plasma lipoproteins. Iso- lation, composition and immunochemical characterization of low density lipoprotein subfractions of human plasma. Biochemistry. 9 : 2244.

39. Gulbrandsen, C., V. Evans, A. Nichols, and R. S. Lees. 1972. Very-low-density lipoprotein metabolism in abetalipoproteinemia. Circulation. 46 (Suppl. 2) : 18.

40. Levy, R. I., M. E. Birnbaumer, and S. Eisenberg. 1971. Plasma lipoproteins. Biochem. Soc. Symp. 33: 3.

41. Barter, P. J., and P. J. Nestel. 1972. Precursor-product relationship between pools of very low density lipoproteins. J. Clin. Invest. 51: 174.

42. Oncley, J. L., and N. R. Harvie. 1969. Lipoproteinsa current perspective of methods and concepts. Proc. Natl. Acad. Sci. U. S. A. $64: 1107$.

43. Goldstein, J. L., H. G. Schrott, W. R. Hazzard, E. L. Bierman, and A. G. Motulsky. 1973. Hyperlipidemia in coronary heart disease. II. Genetic analysis of lipid levels in 176 families and delineation of a new inherited disorder, combined hyperlipidemia. J. Clin. Invest. 52 : 1544.

44. Rose, H. G., P. Kranz, M. Weinstock, J. Juliano, and J. I. Haft. Inheritance of combined hyperlipoproteinemia-evidence for a new lipoprotein phenotype. $\mathrm{Am}$. J. Med. 54 : 148.

45. Schreibman, P. H., D. E. Wilson, and R. A. Arky. 1969. Familial type IV hyperlipoproteinemia. N. Engl. J. Med. $281: 981$.

46. Lees, R. S., D. E. Wilson, G. Schonfeld, and S. Fleet. 1973. The familial dyslipoproteinemias. Prog. Med. Genet. 9 : 237. 